\title{
Research on the Integration of Cross-Cultural Communication and English Teaching in Colleges
}

\author{
Jiao Xue ${ }^{1 *}, \mathrm{Na} \mathrm{Li}^{2}$ \\ 1Jingjiang College of Jiangsu University, Zhenjiang 212013, Jiangsu Province, China \\ 2Zhenjiang Campus of Army Military Transportation College, Zhenjiang 212000, Jiangsu Province, China \\ *Corresponding author: Jiao Xue, shadowvi@163.com
}

\begin{abstract}
The ultimate goal of English teaching in colleges is to cultivate students to have good language skills, enable them to communicate in English in their daily lives, as well as improve their communicative and application skills. The biggest obstacle in the application of English is cross-cultural communication. There are great differences among various cultures, thus leading to ambiguities and misunderstandings in daily communication. Therefore, when training students, college teachers must cultivate professional talents who can face the future and society while improving their cross-cultural communication skills. This article discusses the integration of cross-cultural communication and English teaching in colleges.
\end{abstract}

Keywords: College English; Cross-cultural teaching; Integration

Publication date: June 2021; Online publication: June 30, 2021

\section{Introduction}

With the development of economic globalization and cultural globalization, the goal of English teaching in modern colleges should be to cultivate English applied talents who can be up to par with international standards while understanding the cultural differences and cultural connotations among different countries. With the continuous development of the global cultural environment, English talents are required to face complex ideological collision and cultural integration, analyze the cultural differences of different countries, as well as improve the efficiency of communication and exchange between both parties. Therefore, teachers must pay attention to the cultivation of students' cross-cultural communicative competence in teaching.

\section{Definition of cross-cultural communication}

Cross-cultural communication is also known as intercultural communication. It refers to communication between native speakers and non-native speakers, as well as to any type of communication between people who have differences in terms of language and their cultural backgrounds. English is the most popular language. The goal of English teaching in colleges is to cultivate talents who can face the society and understand the differences among different cultures. In cross-cultural communication, if one party does not have a thorough understanding of the other party's cultural background, it is likely that errors in language expression or use would lead to misunderstandings between both parties. In that case, the communication would not achieve the expected effect, and the learning of that language would lose its original function and significance. English teaching in colleges should pay attention to the cultivation of students' English application skills, which include listening, speaking, reading, and writing skills. These skills need to be based on understanding each other's cultural background in order to be better applied in practice. 


\section{Relationship between cross-cultural education and language education}

Language education is different from that of other subjects. Language education enables students to use language in their daily lives and work responsibilities. Therefore, language education should focus on the improvement of students' personal skills. The ultimate purpose of teaching language is to enable students to understand and apply a certain language in real life. The characteristics of language itself reveal that students should not only learn the meaning of a language but understand the language along with its cultural background in regard to the birth of the language and its historical development. In order for students to use language correctly in communication and exchange with various nationalities, their understanding of that language and its culture should be improved.

First of all, cross-cultural education and language education complement each other. Language education allows students to have a certain understanding of a language. Students must have a good vocabulary reserve and grammar knowledge in order to have basic understanding of a language and to be able to correctly construct a language structure. On the premise of having a certain level of English knowledge, students would then be able to understand the significance of cultural education quicker. Crosscultural education enables students to have a certain understanding of the local customs, morals, and cultural consciousness of different countries. Language education based on culture enables students to further understand the meaning and extended meaning of a language so as to improve their language skills. It can be appreciated that the role between cross-cultural education and language education is complementary; thus, teachers should recognize this in teaching.

Secondly, cross-cultural education and language education are compatible with each other. In language education, through the accumulation of vocabulary and the learning of grammar, students would have a certain understanding of the common expressions and language forms of a certain language. Eventually, they would realize the cultural education contained in language education. In contrast, in cultural education, students would come to appreciate the vocabularies of other languages. Language itself is the epitome of a nation and a country's culture. Language reflects the historical process of a country's progress and development. Therefore, while learning about cultures, students would eventually develop a deeper understanding of a language and recognize the characteristics of the language under different cultural backgrounds. This would improve their mastery of a certain language and their application skills as well as expand their knowledge reserve and horizons.

\section{Integration of cross-cultural communication and English teaching in colleges}

\subsection{Creating language scenes to enhance students' cultural awareness}

If English teachers aspire to integrate cross-cultural communication into their teaching, they need to enable students to understand the use and extended meanings of English while creating various situations that have a cultural atmosphere and environment during their lessons. In addition, teachers should combine the cultural differences of different countries while creating various situations so that students can gradually improve their cultural awareness in specific situations as well as their English application skills.

In this example, the cultural differences between European and American countries would be considered in order to construct a classroom situation. During the teaching, videos would be played via multimedia to reflect the same dialogue but in different cultural backgrounds. In context of the Chinese culture, when introducing a new foreign teacher, it may be common to hear, "Ladies and gentlemen, 'I'm honored to introduce to you a very pretty girl, Miss Brown; she is an excellent teacher from the United States." Such a statement would embarrass American teachers because when Americans meet each other for the first time, they tend not to comment on one's appearance. In the context of American culture, when introducing a person, they would mention the person's position, education, etc. rather than paying attention 
to one's appearance. Therefore, the statement, "I'm honored to introduce to you a very intelligent woman; she came from Oxford University," should be used here to focus on the cultural and professional background of the subject of introduction. This is the difference between Chinese and American cultures. Through this created scenario based on actual situations that could occur, students would come to realize that there are different ways of expressing the same content in different countries, thus deepening their understanding about cross-cultural communication.

\subsection{Giving full play to students' main role and improving their language skills}

The most important aspect while integrating cross-cultural communication into English teaching is to give full play to the main role of students. Students are the main body in the process of learning. Students would be able to explore deeper into the English world by giving full play to their learning initiative. Students should cultivate a more positive attitude while learning in order to improve their personal skills. When cultivating students' communicative competence, first of all, students need to be able to experience cultural differences by themselves so that they can realize the importance of respecting cultural differences independently. This would be an advantage in the learning process.

In order to improve students' learning autonomy and give full play to their main role as students, a student-centered teaching classroom should be emphasized on. For example, based on the subject of crosscultural differences, a time for presentation can be set aside during classroom teaching. Students can then be divided into different groups and activities can be carried out around the theme of "Different Cultures." This would give the students an opportunity to express the theme in various ways, either through their eyes, speeches, performances, or other presentations. In practical teaching, students can be guided to interpret and learn with the theme of "Chinese and American Table Manners." In addition, they can also be encouraged to prepare speeches on "Cultural Differences between Chinese and English Advertisements." Through presentations, students would be able to give full play to their main role and have a deeper understanding of cross-cultural communication.

\subsection{Implementing cross-cultural communication in combination with practice}

Between people, there should be communication. By placing students in a specific language environment where they have to be in contact with different cultures and communicate regardless of the cultural differences, only then can they improve their cross-cultural communication skills. Therefore, it is necessary for teachers to combine cross-cultural communication with practice so that students can recognize the differences among different cultures and improve their English application skills in regard to the cultural background of different countries.

Practical activities should be applied during teaching in order to ensure that students realize the cultural differences among various countries in life communication, thus deepening their understanding of various cultural backgrounds. For example, the 2017 Chinese students' global relay video, "Say my name," can be played during class, and after that, questions about cultural differences can be raised based on the content of the video. Students can then be encouraged to discuss about the stereotypes and prejudices in culture. In this way, they are given the opportunity to analyze the problems and find out the causes of these stereotypes and prejudices by combining their own knowledge with real life cases. As a result, they will learn to appreciate the similarities and differences of different cultures through exploration and analysis. Students will then realize that the premise of applying English is to respect different cultures. Only in this way can students better realize cross-cultural communication. 


\section{Conclusion}

English teachers in colleges need to pay attention to the cultivation of students' cross-cultural communication skills. This would be beneficial for students to understand and respect the different cultures in different countries so that they can communicate based on understanding the differences of cultural backgrounds and eventually build communication bridges with various countries. It is necessary to improve students' cross-cultural communication skills so that they would be able to meet the international standards and grow as English applied talents.

\section{Disclosure statement}

The authors declare that there is no conflict of interest.

\section{References}

[1] Lu M, 2021, One of the "One Belt, One Road" Background of Cross-Cultural Communication Curriculum Teaching Reform in Universities. University Education, (5): 32-35.

[2] Li X, 2021, Research on the Cultivation of Compound Talents for Foreign Language Cross-Cultural Communication in Colleges and Universities Based on Application Orientation. Modern Vocational Education, (15): 58-59. 